\title{
The implementation of sandwich graphic organizer in teaching writing to the tenth grade students of SMAN 1 Jiwan
}

\author{
Puput Karunia Dewi $^{1}$, S. Sumani ${ }^{1}$, Brigitta Septarini ${ }^{3}$ \\ ${ }^{1}$ Department of English Teaching, Universitas PGRI Madiun, Indonesia
}

\begin{tabular}{l}
\hline \hline Article Info \\
\hline Article history: \\
Received January 12, 2018 \\
Revised March 20, 2018 \\
Accepted Mei 29, 2018
\end{tabular}

\section{Keywords:}

Writing

Graphic Organizer

Sandwich Graphic Organizer

\begin{abstract}
This research is conducted to explain the implementation, the problems, and the solutions of problems in the Implementation of Sandwich Graphic Organizer in Teaching Writing to the Tenth Grade Students of SMAN 1 Jiwan in the schooling year of 2016/2017. This research uses descriptive qualitative research. The participants of the research are the English teacher and students of X-A class of SMAN 1 Jiwan. The research uses purposive sampling technique. The techniques which are used to collect the data are observation, interview, and documentation. While, the techniques of the data analysis are: data condensation, data display, and conclusion and verification. The results of this research are the teacher prepares syllabus, $R P P$, and the papers of picture Sandwich Graphic Organizer. The steps are pre-activities, whilst-activities, and post-activities. Otherwise, some students get difficulties in managing their time, some students make mistakes in using V2 that is used in writing recount text, some students get difficulties in expressing their ideas from Indonesian to the English language because of minimum of vocabulary, and some students forget to write a capital letter in the beginning of the sentence and full stop in the ending of the sentence. Then, the solutions of problems in the implementation Sandwich Graphic Organizer are: the teacher explains again about the steps of using technique Sandwich Graphic Organizer, the teacher divides the time of the students when the students should write the outline and when the students should develop their outline, the teacher gives the command for the students to open their dictionary to check the list of verb 2, the teacher asks the students to open their dictionaries when they are difficult in translating their ideas, and the teacher asks the students to pay attention to the punctuation when writing.
\end{abstract}

Copyright $@ 2018$ Department of English Teaching. All rights reserved.

\footnotetext{
Corresponding Author:

Puput Karunia Dewi,

Department of English Teaching,

Universitas PGRI Madiun,

Jalan Setiabudi No.85 Madiun, East Java, Indonesia.

Email: puputkaruniadewi@gmail.com
}

\section{INTRODUCTION}

Among of the four skills that must be mastered by the student, writing is the most important skills in teaching and learning process. By developing their writing skill, the students can communicate effectively in and out of school. It is supported by Santangelo \& Olinghouse (2009:1) that writing is one of the most powerful tools for learning and demonstrating ideas in writing class. In developing the writing skill of the students, the teacher has important role in giving information and knowledge about some basic competences that must be mastered by the students, they are the right step in organizing ideas, grammar and punctuation, also the coherent content. Writing class is expected to help students to produce a good writing. 
The problems in developing writing skills of the students are about how to optimize the learning process in order to achieve the expected results. There are some problems that are found in the tenth grade students of SMAN 1 Jiwan: 1) the students are difficult to choose the topic that will be writing. 2) The students are difficult to make good sentences. It is caused by minimum knowledge about the material and vocabulary. 3) They are also difficult in organizing their ideas, and have less motivation. It is caused by the teacher who does not use appropriate methods or strategies in teaching writing. The teacher simply gives the order to follow the writing class and to do tasks from the teacher. This condition makes the students feel bored and have less motivation to follow the learning English.

One way that can be used to optimize the learning process of writing class and to improve the motivation of the students is giving the variation technique in the teaching writing class. The appropriate technique can make the student easy to write good writing.

Writing class will be enjoyable if the students know the first step to start writing. There are some processes of writing: the first is planning, the second is drafting, the third is editing, the fourth is final version (Harmer, 2004:4-5).

The problems of students in organizing ideas can be solved by using technique Sandwich Graphic Organizer in writing class. Sandwich Graphic Organizer can help students to produce coherent sentences and not turn out from the topics or main idea that the students choose. Miller (2011:4) states that graphic organizers serve as visual representation of ideas that help learners organize their thoughts and apply their thinking skills to the content in a more orderly manner. Miller further adds that graphic organizers "often occur in the form of key words and allow students to focus more on the meaning rather than the format of complete sentence structure". It means that Sandwich Graphic Organizer can be used as a tool in writing class to produce visual image. And also can be used to organize ideas to produce good writing.

The researcher finds some previous researches related to this research. First, a research was done by Irawati. L. et.al, (2014) study entitled "Implementasi Sandwich Graphic Organizer untuk Meningkatkan Kemampuan Menulis Esei Mahasiswa Semester III”. This classroom action research aimed to know weather Sandwich Graphic Organizer technique can improve students' ability in writing essay and to know the strengthen and weaknesses of using sandwich graphic organizer for three semester college students. The result of the research shows that Sandwich Graphic Organizer can improve the ability of students in writing argumentative essay. It is proven by participants' mean score in writing increase from 62 in pretest to 75 in post test I and 79 in post test II.

The second research was done by Majeed Tayeeb (2015) study entitled "The Effect of Using Graphic Organizers on Writing (A Case Study of Preparatory College Students at UMM-Al-Qura University). This classroom action research is aimed to investigate the effectiveness of graphic organizers on students' writing ability as well as their attitudes towards this essential language skill. The results of the research proved that graphic organizers model can improve the students' writing ability. It is proven by participants' mean score in writing increase from 45 in before training to 68.88 in after training.

Based on phenomena above, the researcher is interested in conducting a research entitled "The Implementation of Sandwich Graphic Organizer in Teaching Writing to the Tenth Grade Students of SMAN 1 Jiwan in Schooling Year of 2016/2017”. 


\section{METHOD}

This research uses descriptive qualitative research. The participants of the research are the English teacher and students of X-A class of SMAN 1 Jiwan. The research uses purposive sampling technique. In this research, the researcher used triangulation as the technique of collecting data. The types of triangulation are: first is data triangulation involves time, space, and person. The second is investigator triangulation involves multiple researchers in an investigation. The third is theory triangulation involves using more than one theoretical scheme in the interpretation of the phenomenon. The fourth is methodological triangulation involves using more than one method to gather data such as interviews, observations, questionnaries, and documents. In this research, the researcher used methodological triangulation to produce a valid data, the method are observation, interview, and documentation. In observation the researcher observes the activity of using technique Sandwich Graphic Organizer during the teaching and learning process. While, in interview the researcher interview the English Teacher and 10 students of XA Class. Meanwhile in documentation the researcher uses Lesson Plan, syllabus, photograph, students' score, students attendance list. While the data analysis in this research there are three activities to data analysis, they are: data reduction, data display, and conclusion drawing/verification. It is supported by Miles and Huberman 2014:8-10). They are: 1) Data condensation. In this stage, is the process of selecting, focusing, simplifying, abstracting, and/or transforming the data that appear in the full corpus (body) of written-up field notes, interview transcripts, documents, and other empirical materials

In this research the researcher collects data from observation, interview, and documentation of X-A SMAN 1 Jiwan Student's in Implementation of Sandwich Graphic Organizer in Teaching Writing Recount Text in the Schooling Year 2016/2017. 2) Data display. Data display is an organized, compressed and assembly of information that allows conclusion drawing and action. The researcher uses data display compiling a list of events in the form of narratives when display the result of observation and interview, while in display the score of the student's writing the researcher uses tables. The researcher arranges the chronological of teaching and learning process then makes the simple note to understand all events in the research of Implementation of Sandwich Graphic Organizer in Teaching Writing Recount Text to the Tenth Grade Students of SMAN 1 Jiwan in Schooling Years 2016/2017. 3) Conclusions drawing and Verification. In this stage is the process for reducing and displaying data is to assist in drawing conclusion. In this activity, researcher concludes the finding of the research to give clear explanation of what the researcher's analysis is mainly about. The researcher concludes the problems and solutions of problems from Implementation of Sandwich Graphic Organizer in Teaching Writing Recount Text to the Tenth Grade Students of SMA 1 Jiwan in Schooling Years 2016/2017.

\section{RESULTS AND DISCUSSION}

The research gets research finding from the implementation of teaching writing by using Sandwich Graphic Organizer technique for the tenth-grade students of SMAN 1 Jiwan in the Schooling year of 2016/2017. The implementation of Sandwich Graphic Organizer is divided into two. The first is preparation step. In this step, the teacher prepares materials, syllabus, RPP, and media such as: picture Sandwich, and book materials. The second is presentation step. In this step, the learning activities of teaching writing used 
Sandwich Graphic Organizer is divided into three steps, they are: Pre-activities, Whilst-activities, Postactivities.

In pre-activities, the teacher greets the students and asks to pray together. Then the teacher checks the attendance list by calling the name of the students one by one. After that the teacher does apperception related with the material to build the background knowledge of the students.

In the whilst-activities, the teacher explains about the definition, purpose, generic structures, and language features of recount text. After that the teacher gives the example of recount text and asks the students to analyze the generic structures and language features. Then, the teacher distributes the papers that consist of pictures Sandwich and explains about what the students do with the picture. The students make an outline based on their experiences, and develop their ideas. After that, the students collect their assignment.

In post activities, the teacher gives a chance to the students to ask about their difficulty. The teacher closes the meeting and says goodbye.

There are some problems of using technique Sandwich Graphic Organizer in teaching writing were given in the following:

a. Some students are still confused about the steps how to use Sandwich Graphic Organizer.

b. Some students get difficulties in managing their time, when the students should write their outline and when the students should develop their ideas.

c. Some students make mistakes in using V2 that is used in writing recount text.

d. Some students get difficulties in expressing their ideas from Indonesian to the English language because of minimum of vocabulary.

e. Some students forget to write a capital letter in the beginning of the sentence and full stop in the ending of the sentence.

There are five solutions of problems in using technique Sandwich Organizer in teaching writing were given in the following:

a. The teacher explains again about the steps of using technique Sandwich Graphic Organizer.

b. The teacher divides the time of the students when the students should write the outline and when the students should develop their outline.

c. The teacher gives the command for the students to open their dictionary to check the list of verb 2 .

d. The teacher asks the students to open their dictionaries when they are difficult in translating their ideas from Indonesian to the English language.

e. The teacher asks the students to pay attention to the punctuation and capital letter when writing.

In the discussion, the researcher presents the results of discussion between this research with the theory of the implementation Sandwich Graphic Organizer in teaching writing. The steps of using Sandwich Graphic Organizer are described as follows:

a.) The teacher gives the material about recount text. First the teacher explains about the definition, the purpose, the generic structures and language features of recount text.

b.) The teacher gives the example of recount text and distributes to the students.

c.) The teacher asks the students to analyze the generic structures based on the example of recount text.

d.) The teacher distributes the papers that consist of picture sandwich. 


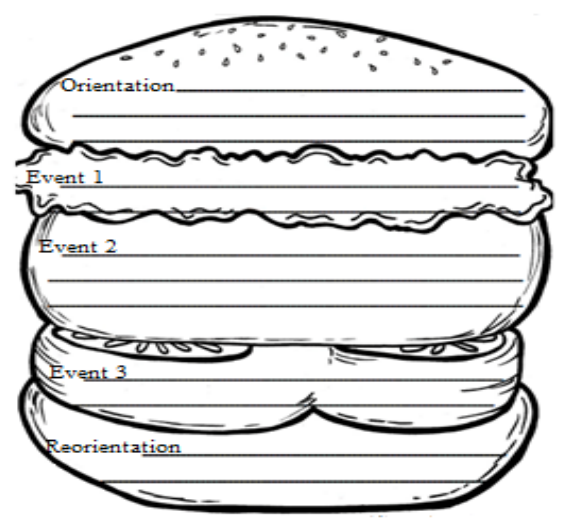

e.) The teacher explains about how to use Sandwich Graphic Organizer. First explanation is about the structures of of Sandwich Graphic Organizer. Every part has different function, like the first part is top bun. In the top bun, the students should write ideas about orientation. Then in the lettuce, meat, and tomatto as the the second, third, and fourth part, the students should write ideas about the events. And the last part, bottom bun, the students should write about re-orientation. Those activities are relevant with Section VI Models and Graphic Organizer (2003:38) states that the teacher should introduce the Sandwich Graphic Organizer by showing students the top bun and the bottom bun which represent the introduction and conclusion, and the teacher also note that meat and vegetables part represent the supports of thesis statement.

f.) The teacher asks the students to make outline.

g.) The teacher asks the students to develop their listing of ideas into a good recount text.

h.) The teacher asks the students to submit their worksheet in the teacher's table.

The series of activities in whilst-activities are supported by journal of using Sandwich Graphic Organizer in teaching writing (Irawati.L. et.al, 2014:26). In applying Graphic Sandwich Organizer in teaching writing there are some procedures that should be paid attention. The procedure of using Sandwich Graphic Organizer can be described as follows:

a) The first step is the students prepare articles or other sources information that associated with idea of the topics that is developed in writing essay.

b) The second is prewriting process. In this steps the students grouping the ideas based on the articles that has been read by the students with technique listing, clustering or mapping.

c) The third step is outlining. In this step the students incorporate their ideas in pattern of Graphic Sandwich Organizer there is writing thesis statement in introduction, topic sentence in every part of body from Sandwich, and conclusion in the bottom part of sandwich. In the sandwich, the students also can incorporate supporting detail that can make the student easy when writing essay.

Based on the explanation above, it can be concluded that the implementation of Sandwich Graphic Organizer in teaching writing are different with the teaching procedures from journal of using Sandwich Graphic Organizer by (Irawati.L. et.al, 2014:26). There are some differences of the teaching procedures between the teacher and journal by Irawati. L. 
The first difference can be viewed from material of using Sandwich Graphic Organizer. In journal by Irawati.L, the technique Sandwich Graphic Organizer is used to teach writing essay. While in this research, the technique is used to teach writing recount text.

The second difference can be viewed from the steps of using Sandwich Graphic Organizer. In journal by Irawati.L, the first step is the students prepare articles or other sources information that associated with idea of the topics that is developed in writing essay. While in this research the students remember ideas related with the events in the past time.

The third difference can be viewed from the technique of grouping ideas. In journal by Irawati.L in prewriting process the students must grouping the ideas based on the articles that has been read by the students with technique listing, clustering or mapping.

In this research, there are some problems of using technique Sandwich Graphic Organizer in teaching writing were given in the following:

a. First, there are some students are still confused about the steps how to use Sandwich Graphic Organizer.

By using this technique, some students are still confused in using this technique. Based on the teacher's interview, the teacher says that, "I find they are some students that still confused about the step how to use Sandwich Graphic Organizer". It means that some students are still confused in using technique Sandwich Graphic Organizer. While, based on the observation by the researcher, some students ask with their friend about some steps in using Sandwich Graphic Organizer so it means that the students are still confused about the steps how to use Sandwich Graphic Organizer.

b. Second, there are some some students get difficulties in managing their time, when the students should write their outline and when the students should develop their ideas.

By using this technique, some students get difficulties in managing their time, when the students should write their outline and when the students should develop their ideas. While, based on the teacher's interview, the teacher says that, "I find some students get difficulties in managing their time, when the students should write their outline and when the students should develop their ideas". It means that some students still difficult in managing their time, when the students should write their outline and when the students should develop their ideas

c. Third, there are some students make mistakes in using V2 that is used in writing recount text.

By using this technique, some students make mistakes in using V2 that is used in writing recount text. Based on the teacher's interview, the teacher says that, "I find some students are wrong in writing the form of a verb that is used in writing their recount text". It means that the teacher finds some students make a mistake in using verb 2 . While, based on the observation the researcher find some students make mistakes in writing the form of a verb in writing recount text. So it can be concluded that there are some students get difficulties in the correct form of verb 2 used in writing recount text.

d. Fourth, there are some students get difficulties in expressing their ideas from Indonesian to the English language because of minimum of vocabulary. 
By using this technique, some students get difficulties in expressing their ideas from Indonesian to the English language because of minimum of vocabulary. Based on the teacher's interview, the teacher says that, "There are some students that are difficult in express their ideas from Indonesian to the English language causes a minimum of vocabulary" (see appendix 5). It means that the teacher finds some students get difficulties in expressing their ideas. While, based on the observation the researcher find there are some students opened their dictionary because they had the minimum vocabulary. So it can be concluded that there are some students get difficulties in expressing their ideas.

e. Fifth, there are some students forget to write a capital letter in the beginning of the sentence and full stop in the ending of the sentence.

By using this technique, some students forget to write a capital letter in the beginning of the sentence and full stop in the ending of the sentence. Based on the teacher's interview, the teacher says that, "There are some students that forget to write a capital letter at the beginning of the sentence and full stop in the ending of the sentence"(see appendix 5). It means that the teacher finds some students get difficulties in punctuation. While, based on the observation the researcher find there are some students forget to write capital letter in the beginning of the sentences and full stop in the ending of the sentences.. So it can be concluded that there are some students get difficulties in writing capitalization and punctuation.

While, based on the journal by Irawati.L. et.al, 2014:30) there are five problems in the implementation Sandwich Graphic Organizer.

a. First in prewriting process. There are some students get difficulties in exploring their ideas, and in the outlining stages some students still confused to put their ideas in the pattern of Sandwich Graphic Organizer.

b. In drafting process. There are some students make a mistake in using the right grammar and got difficulty in selection appropriate vocabulary, punctuation, and proper spelling.

c. In responding process. There are some students are not confident in giving responds and advices because minimum of knowledge about content and grammatical.

d. In revising process. There are some students still cannot revise the grammar and mechanical perfectly.

e. In evaluating process. There are minimum time to check the result of writing by the students, so the lecturer just explain the students' issues generally in front of the class.

Based on the journal and this research, it can be conlcuded that there are some problems which are same in the implementation Sandwich Graphic Organizer, they are described as follows: first there are some students get difficulties in exploring their ideas, some students still confuse to put their ideas in the pattern of Sandwich Graphic Organizer, some students make a mistake in using the right grammar and get difficulty in selection appropriate vocabulary, punctuation, and proper spelling.

While in this research there is new finding in problem of implementation Sandwich Graphic Organizer: there are some students get difficulties in managing their time, when the students should write their outline and when the students should develop their ideas. 
There are five solutions of using technique Sandwich Organizer in teaching writing were given in the following:

a. First, the teacher explains again about the steps of using technique Sandwich Graphic Organizer.

Based on the solutions of problems in using Sandwich Graphic Organizer, the teacher explains twice about the steps of using this technique. Based on the teacher's interview, the teacher says that, "I explain twice to make sure that the students already know about how to use Sandwich Graphic Organizer". It means that the teacher explains again about the steps of using this technique. While, based on the observation the researcher find the teacher asks the students about who are still confused about how to use this technique, then the teacher explains again. So it can be concluded that that the teacher explains again about the steps how to use this technique.

b. Second, the teacher divides the time of the students when the students should write the outline and when the students should develop their outline.

Based on the solutions of problems in using Sandwich Graphic Organizer, the teacher divides the time of the students when the students should write the outline and when the students should develop their outline. Based on the teacher's interview, the teacher says that, "I divide the time of writing class, when the students should write an outline and developing their outline". It means that the teacher divides the time of the students.

c. Third, the teacher gives the command for the students to open their dictionary to check the list of verb 2 .

Based on the solutions of problems in using Sandwich Graphic Organizer, the teacher gives the command for the students to open their dictionary to check the list of verb 2. Based on the teacher's interview, the teacher says that, "I give the command to the students to open dictionaries to check the form of a verb that is written by the students is right". It means that the teacher give command to open dictionary. While, based on the observation the researcher find the teacher asks them to open their dictionary to check the form of verb 2 . So it can be concluded that that the teacher gives the command for the students to open their dictionary to check the list of verb 2.

d. Fourth, the teacher asks the students to open their dictionaries when they are difficult in translating their ideas from Indonesian to the English language.

Based on the solutions of problems in using Sandwich Graphic Organizer, the teacher asks the students to open their dictionaries when they are difficult in translating their ideas from Indonesian to the English language. Based on the teacher's interview, the teacher says that "I ask the students to open their dictionaries when they are difficult in translate their ideas from Indonesian to the English language”. It means that the teacher give command to open dictionary when the students difficult in expressing their ideas. While, based on the observation the researcher find the teacher gives command to open dictionary. So it can be concluded that that the teacher asks the students to open their dictionaries when they are difficult in translating their ideas from Indonesian to the English language.

e. Fifth, the teacher asks the students to pay attention to the punctuation when writing.

Based on the solutions of problems in using Sandwich Graphic Organizer, the teacher asks the students to pay attention to the punctuation when writing. Based on the teacher's interview, the teacher says that "I remember the students to pay attention to the punctuation and capital letter when writing". It 
means that the teacher gives command to pay attention in punctuation and capital letter. While, based on the observation the researcher finds the teacher gives command to pay attention with the punctuation and capital letter. So it can be concluded that the teacher asks the students to pay attention to the punctuation when writing.

While, based on journal by Irawati L. et.al, 2014:32) there are five solutions of problems in the implementation Sandwich Graphic Organizer.

a. In prewriting process, the lecturer does not only facilitate articles from newspapers but the students may explore their ideas by searching articles from internet or other sources.

b. In drafting process, the lecturer supplies with additional material about grammatical, mechanics, also selection appropriate vocabulary.

c. In responding process, if the student did not get difficulties with grammatical, mechanics and vocabulary, so the students did not get difficulty in giving responds for their students' assignment.

d. In revising process, the students can revise their content besides grammar and mechanic with the way of editing practice.

e. In evaluating process, there is an additional schedule outside the schedule of writing class so that the intensity of meeting between lecture and students more in discussing about essay.

Based on the journal and this research about the solutions of the problems in the implementation Sandwich Graphic Organizer, it can be concluded that, the researcher find some new solutions of problems in the implementation of Sandwich Graphic Organizer: first for the students that still confuse about how to use this technique, the teacher explains again about the steps of using technique Sandwich Graphic Organizer. The second, for the students which are get difficulties in managing their time, the teacher divides the time of the students, when the students should write the outline and when the students developing their outline. The third, for the students who make a mistake is writing correct verb, the students to open their dictionary to check the form of verb that is written by the students is right. The fourth, for the students who get difficulties in translating their ideas from Indonesian to English language can open their dictionaries. The fifth, for the students who get difficulty in punctuation can be solved with the teachers' command for the students to pay attention with the punctuation when writing.

\section{CONCLUSION}

Sandwich Graphic Organizer is one of techniques that can be used to make students easily to organize their ideas in writing class with the material about recount text and as to make the students enjoy teaching and learning process.

The procedures of using Sandwich Graphic Organizer in Teaching Writing to the Tenth Grade Students of SMAN 1 Jiwan in the Schooling years of 2016/2017 are divided into some steps. First is preparation activities, the teacher prepares the material and lesson plan before doing teaching and learning process. Then, in appliying Sandwich Graphic Organizer the teacher uses three steps: pre-activities, whilst-activities and post-activities. In pre-activities, the teacher starts the teaching learning process by giving greeting to the students, asks the leader of X-A class leading to pray, asks the students' condition, checks the students attendance list, giving apperception. Then the teacher give the material about recount text, such as: the definition, purpose, generic structure, and language features of recount text. Then, the teacher gives the 
example of recount text, and asks the students to analyze the generic structure. After that the teacher explain about how to use Sandwich Graphic Organizer, asks the students to incorporate their ideas in the part of sandwich, developing their ideas. Finally, the teacher asks the students to collect their assignments.

There are some problems found by the researcher in the implementation of Sandwich Graphic Organizer in Teaching Writing to the Tenth Grade Students of SMAN 1 Jiwan. First, there are some students are still confused how to express their ideas in the pattern of Sandwich Graphic Organizer. Second, there are some some students get difficulties in managing their time, when the students should write their outline and when the students should develop their ideas. Third, there are some students make mistakes in using V2 used in writing recount text. Fourth, there are some students get difficulties in expressing their ideas from Indonesian to the English language because of minimum of vocabulary. Fifth, there are some students forget to write a capital letter in the beginning of the sentence and full stop in the ending of the sentence.

The are solutions of problems are arised in the implementation of Sandwich Graphic Organizer in Teaching Writing to the Tenth Grade Students of SMAN 1 Jiwan. First, the teacher explains again about the steps of using technique Sandwich Graphic Organizer. Second, the teacher divides the time of the students when the students should write the outline and when the students should develop their outline. Third, the teacher gives the command for the students to open their dictionary to check the list of verb 2 . Fourth, the teacher asks the students to open their dictionaries when they are difficult in translating their ideas from Indonesian to the English language. Fifth, the teacher asks the students to pay attention to the punctuation when writing.

\section{REFERENCES}

Harmer, J. (2004). How to Teach Writing. England: Person Education Limited

Irawati, L., Lestari, Sri, \& Wahyuni, T. (2014). Implementasi Sandwich Graphic Organizer Untuk Meningkatkan Kemampuan Menulis Esei Mahasiswa Semester III. Jurnal LPPM. 2(1): 25-33. (http://e-journal.unipma.ac.id/index.php/JP-LPPM/article/view/347)

Miles, M.B. \& Huberman, A. M. (2014). Qualitative Data Analysis. United States of America: SAGE Publication, Inc.

Miller, S.A. (2011). Using Graphic Organizer to Increase Writing Performance. Tesis tidak diterbitkan. New York: Department of Language, Learning and Leadership. Fedonia State University of New York.

Oregon Department of Education Office of Special Education Talented and Gifted. (2003). Challenging High end Learners: Addressing Oregon Standart and Benchmark Section VI Models and Graphic Organizer.

(https://wou.edu/education/resources/tagresource/pdf_sections/section_vi_models_graphic_organi zer.pdf)

Santangelo, T \& Olinghouse, N. (2009). Effective Writing Instruction for Students who have Writing $\begin{array}{lllll}\text { Difficulties. } & \text { Focus }\end{array}$ (https://writingsubcommittee.wikispaces.com)

Tayib, A. M. (2015). The Effect of Using Graphic Organizer on Writing. International Journal of English Language and Linguistics Research. 3(1): 15-36. (www.eajournals.org) 